\title{
The Contraction of European Economic Distances through Sustainable Tourism in the Pre-Pandemic Period
}

\author{
Alina - Petronela Haller
}

\begin{abstract}
The current importance of tourism leads us to analyze the extent to which the receipts from international tourism, and tourism in general, influence the capacity of European countries to reduce the development gaps of this sector in the European context and the extent to which the economic growth is sensitive to changes in tourist arrivals, tourism receipts and expenditures. Studying the GDP per capita and the receipts from international tourism for the period 1995-2017, we find that the European tourism has an important role in economy but secondary to capital stock and exports. The methodology used is a sensitivity analysis and a multiple linear regression with two models.

The results show that, on short term, the gap in the European tourism sector is explained by the ability to attract income from the international tourism. The European growth of the tourism sector depends to a large extent on the amount of expenditures that tourists are making, on tourism receipts and, to a lesser extent, on tourist arrivals, but in all cases, the connection is a direct and positive one but, even so, the capital stock and the exports continue to play a very important role for the European economy. The analysis suggests that tourism is not a panacea for growth. On the contrary, it is one of the activities that stimulate growth along with investments, technology, or any other form of capital, together with exports and labor market conditions.
\end{abstract}

Keywords: European growth; tourism expenditures; tourism receipts; tourism arrivals; capital stock; exports

JEL Classification: O10, O47, O52, Z32

\footnotetext{
" Alina - Petronela Haller, PhD Senior Researcher, Romanian Academy Branch of Iasi - "Gh. Zane" Institute for Economic and Social Research, Codrescu Str., No. 2, Iasi, Romania. alina.haller@acadiasi.ro
} 


\section{Introduction}

Tourism is an activity specific to the tertiary sector which experiences the fastest growth (Agnew \& Viner, 2001; Copp \& Lvy, 2001; Weforum, 2019; UNWTO, 2019) and one of the most important sectors of the global economy (Gössling et al., 2005) representing the third largest export category worldwide after the chemical industry, the oil industry and the automotive industry (UNWTO, 2018a). No country can rely solely on tourism as a source of income, but it is an important factor for growth, especially through the related effects in construction, transport, infrastructure and food (UNWTO, 2018b).

The dynamism and the context of the current life guide the economic entities towards the necessity of developing the tourist activity, not only in the areas with a tourist tradition. For example, in 2001, 49 developing countries attracted only $1 \%$ of global tourists (Robinson \& Picard, 2006). Nowadays, a considerable number of developing countries live mainly from tourism, and hence the need to develop this activity and to give it industry-like textures, including on European soil.

Tourism includes activities specific to those who travel or go to a place other than their permanent residence for a period of less than one year in order to enjoy, to do business or for other purposes (Dabour, 2003, Mckerscher \& Lew, 2004, Greg, 2005). It involves the movement of people in time and space, between their habitat and other regions and the choice of a holiday destination depends directly upon the needs and expectations of tourists (Mckercher \& Lew, 2004).

The tourism industry has grown almost everywhere in the world and has generated earnings for both the receiving countries as well as for the generating countries. The diverse natural, geographical, historical or cultural resources provide a vast potential for tourism development that is not always easy to achieve. The most important obstacles to tourism development are the lack of attractions, technical/procedural knowledge/know-how, the lack of adequate promotion, tourist infrastructure (hotels, hostels, transportation, communications, information points), the lack of investments, the lack of tourism diversification and safety, the mistrust in tourism as a profitable activity or as an economic and social progress, the incoherent tourism policies and strategies, not integrated in the strategies of national development, etc.

These obstacles are faced in particular by the less developed countries. But, on the other hand, the intensification of the social relationships all over the world, partly due to communication technologies, transport and financial systems that imprint all dimensions of life help the development of tourism industry.

Tourism grows as industrialization and urbanization reach ever higher levels, and the tourism efficiency is increasing as a result of improving the locals' education (Tsai, 2007), which brings tourism as a value-creating activity.

The development of the tourism sector and industry is influenced by social trends, in particular by the leisure preferences, by pronounced individualism, demographic 
shifts, and economic, technological and communicative progress, trends that make their mark on increasingly complex products (Abicht \& Freikamp, 2005; Henriksson, 2005) and on the environment affected by the human insertion meant to increase the well-being.

From the viewpoint of tourist destinations, regardless of the type of tourism practiced, Europe remains the main destination of the world (Strietska-Ilina \& Tessaring (eds.), 2005; Bohdanowiez, 2005; Fossati et al., 2000; Richards (ed.), 1996; UNWTO, 2018a; Weforum, 2019) and continues to be a tourism power center acting as a catalyst for economic expansion, job creation and the socio-cultural development.

The effects of tourism in Europe are direct, indirect and induced, with an important role in the industry played by tradition. In 2017, Europe attracted $51 \%$ of the total arrivals and 39\% of the total tourism revenue (UNWTO, 2018a). Until 2030 forecasts foresee a continued development of the tourism activity (UNWTO, 2019). The year 2017 marked Europe's eighth year of sustained growth, as it was the most visited destination in the world, especially due to the attractiveness of Mediterranean region (UNWTO, 2018a).

The European territory includes countries with a wealthy and renowned tourist, historical, cultural and geographical heritage that imposes them as destinations and as motivational examples for tourism and economic development of the less developed European countries, especially in the Center and at the East of the continent. In Europe, culture and tourism have always been linked (Richards, 1996); tourism allowed people to interact with the places they admired once associated with characters, writers, painters or historical events (Herbert, 1996). It is necessary to mention, however, that in recent years, the Asia-Pacific region has achieved remarkable results in the tourism sector. For example, in 2017, Asia-Pacific registered 324 million tourists, a quarter of the total, half of the most visited cities in the world were from this region, being the second region of the world in terms of tourist arrivals, but an important feature of tourism is that $80 \%$ of tourist traffic in Asia-Pacific is intraregional; Asia-Pacific is the region where most spending on tourism in the world has been made, especially in the case of intra-regional travel (Horwath HTL, 2018; Weforum, 2019). Asia-Pacific is emerging as a real competitor for Europe and Eurasia, but European region continues to remain the most competitive in terms of tourism having as main factor of attractiveness the cultural resources concentrated mainly in Southern and Western Europe (Weforum, 2019).

The CEE countries are becoming increasingly attractive as the value of investments in the region increased from EUR 448 million to EUR 3500 million between 2003 and 2017 (Invest Europe, 2018). The tourist attractiveness and the efforts of the CEE countries to find solutions and to use the most efficient levers of economic growth leads us to analyze the extent to which they are able to turn tourism into a factor of progress similar to what exists in the rest of Europe. CEE countries are not a cultural and historical brand, but they enjoy a high natural potential that allows them 
to be promoted as destinations for various forms of sustainable tourism while recognized European destinations make the effort to turn tourism into an increasingly sustainable activity. Despite the limits of the research, we note the encouraging results obtained confirming the ability of the CEE economies to develop their tourism and to reduce, at different rates, the gaps compared to the established tourist destinations and also to note that although tourism is not a panacea, it remains an important growth factor for European countries.

The research objective will be achieved using a mixt of methods, a deterministic analysis of the elasticity coefficients - a sensitivity analysis, and a multiple regression analysis to reveal the link between the variables.

We have structured the study in the Literature Review, where we reviewed a series of results obtained by other researchers concerned with this subject, in Method and Methodology, where we presented the indicators and methods used, in Results and Discussions where we synthesized and interpreted the results obtained and we finish with Conclusions.

\section{Literature Review}

In our attention is tourism in its sustainable form. Lately, it is discussing more and more about tourism in relation to the environment, being necessary for this activity to become sustainable. We note the interest in the impact of tourism upon the environment and upon the effects of climate change on tourism. Sharpley (2020) notes that intensifying tourism activities is a major challenge for many destinations. From an economic point of view, tourism is a source of income for local communities but from an ecological point of view it is a challenge for the environment, the sustainability of tourism assuming that this activity has minimal negative impact on destinations and a positive impact on society (Filipiak et al, 2020). Sustainable tourism is not a special form of tourism activities, according to Radovanov et al (2020), but all forms of tourism must aspire to be sustainable because most tourists want to visit clean places where the level of pollution is low. Sustainability is, according to Okumus \& Erdogan (2021), a holistic approach whose components are economic, environmental and social and which strikes a balance between social needs and resource sustainability. Conceptually, sustainable tourism arose from the need to improve the tourism industry as a whole, and its objective is to ensure that the resources available to the tourism industry are in a sustainable balance (Radovanov et al, 2020). The most interested in sustainability are the residents of tourist destinations, there is an interest from entrepreneurs and public administration, and the least concerned about these issues are the tourists themselves (Rasoolimanesh et al, 2020) but they want to spend their free time in a sustainable environment. We start from the premise that the sustainability of tourism must be a goal, and tourism in the future, if it will not 
be sustainable, will at least try to imprint this characteristic on it. The sustainable tourism is, according to Góssling et al (2005), a key concept for the researchers in the field since the early 1990 s, because the tourism development must be sustainable but the way in which this is achieved remains questionable.

The impact of tourism on the diversity and fragility of the environment implies, from Hall's standpoint (2000), a great deal of attention, planning and monitoring. Fossati \& Panella (2000) characterize the tourism activity through three elements: the idea of movement, the idea of a person's behavior as a tourist and the idea of the environment or action space, and the sustainability of tourism poses the issue of growth as a process of change in which the exploitation of resources, the targeting of investments, the development orientation and technological change are tailored to present and future needs. The same authors believe that the degradation of the environment is one of the factors leading to the decrease of the number of tourists in some regions.

Agnew and Viner (2001), in an analysis of the possible impact of climate change on 10 international tourist destinations, conclude that the raising global temperatures will have important consequences for the tourism industry, depending on temperature and environment, as many destinations are vulnerable to changes in the climate and ecosystem.

The natural environment, according to Bohdanowiez (2005), is the most exposed to overexploitation, as tourism services, especially those provided by hotels, it is intensive in resources, leading to environmental degradation and to global warming. Lars et al (2009) note, as they explored the tourism in the case of Spain, that this activity is strongly affected by climate change. Grillakis et al (2016), in an analysis of the impact of two-degree warming on the European summer tourism, conclude that tourism is dependent upon the climatic conditions in certain destinations, and in the future - 2031-2060 - there is a possibility that the Central and Northern Europe may be positively affected but not the Mediterranean countries, which will result in a redistribution of tourists' flows across the continent as well as a seasonal redistribution. All these challenges related to rising temperatures and global warming invoke sustainability as the umbrella under which future economic activities will take place, including tourism.

Hall (2011) believes that there are some trends that will influence the CEE countries with the climate change such as the reorientation towards domestic tourism to the detriment of the international one, the interruption of continuity in the planning of destinations, the increased flow of tourists from Southern Europe, the reduced seasons, the loss of attractiveness as a result of the development of Asian and South American markets, in which case the CEE countries should identify the less sensitive climate tourism, alternative strategies for restricting the tourist activity and closely monitor the global tourism trends.

The development of sustainable tourism is strongly correlated with that of transport, especially air transport. Gôssling et al. (2005) conclude that tourism is not a 
more environmentally friendly activity compared to others, and the mode of transport and the distance of travels influence the eco-efficiency of tourism. Graham and Shaw (2008) argue that there is an incompatibility between the sustainability of the environment and the development of transport models, especially the air transportation, given that sustainability involves a mixture of economic, social and environmental processes, and the problem is acute in the field of transport which obviously creates externalities on the environment but is also a key factor for growth and development. Yang and Nair (2014), in a theoretical analysis of safety and security risks in tourism, believes that the development of transport, especially the air transport, has enabled tourism to turn from an activity once reserved to the rich people into an activity available to the masses and an important factor poising the balance of payments. Development of transport and lower costs have stimulated tourism but also have affected the environment, increased pollution and global warming and raised the issue of sustainability.

In CEE there are countries whose tourism sector is more or less prone to be sustainable. Augustyn (1998) assessed, on the example of Poland, the extent to which the national development strategies for rural tourism lead to sustainability, noting that the role of tourism has changed substantially, as it became an important factor of development and sustainability. The author believes that there is no universal rule or practice to attain the objectives of development and sustainability at the same time, but there is a need for a strategy based upon diversity and experience specific to a country or region. Nowacki et al (2018) show that in Poland there are problems in implementing the principles of sustainable tourism given that, according to Zarebski et al (2019) tourism has developed rapidly and unsustainably which has led to investment in the sustainable development of this sector.

The analysis of the Czech tourism industry reveals that starting with 2011, which marks a rapid increase in the accommodation capacity, the emphasis is placed upon sustainability due to the social, economic and environmental problems that may arise in the future, according to the results obtained by Jurigova (2016). Assessing the sustainable tourism potential in the Czech Republic, Havliková (2019) noted the existence of negative effects of tourism such as excessive infrastructure and inadequate housing, legislative shortcomings and insufficient environmental education.

In Romania, rural areas have the potential for sustainable tourism in the form of agrotourism (Marian, 2017), but sustainable tourism is encouraged even in urban areas (Tătar et al, 2018). In Bulgaria there has been a stable development of sustainable tourism (Doncheva, 2019; Vodenska, 2020). Slovakia has experienced positive changes in the development of sustainable tourism in almost all its territory (Štefko et al, 2018), Slovenia needs institutional support to develop sustainable tourism (Korez-Vide, 2017), Estonia has made rapid progress with a focus on rural tourism development (Ruukel et al, 2020), in Hungary the development of tourism is a strategic objective that needs the involvement of the authorities in order to reorganize 
the sector especially in rural areas (Lakner et al, 2018), Lithuania needs a long-term strategy in this sense (2019), Latvia promotes slow tourism as a form of sustainable tourism (Serdane, 2020), being one of the greenest European states hence with a high potential to practice sustainable tourism (Eglite \& Kaufmane, 2019), while in Croatia the instrument for the development of sustainable tourism is the rural environment without the process being fully realized (Kantar \& Svržnjak, 2017).

Ana (2017) has studied tourism in the new EU member states from the date of accession until 2014 and agrees that the new member states, in this case the CEE countries, do not have the ability to compete with key players on the European tourism market - France, Spain, UK, Italy, Germany - as they are new destinations, untapped and not yet known, and Poland, Czech Republic and Croatia are the most attractive countries in terms of tourism in the region. Romania and Bulgaria are very different from the rest of the EU-28 states; according to Figuet \& Nenovsky (2006), they have, as Wojciech (2016) points out, a high degree of similarity and together they form a "divergent object". Iorio \& Corsale (2010) study the case of Romania noting that this is still a predominantly rural and agricultural country (Andrei et al, 2017), where agriculture is a basic activity offering a low living standard for the population, but with attractive rich culture and landscapes in the rural areas. However, Romania is not considered a main destination in the European context.

In the situation of the CEE countries many authors identify the tourist importance of the rural environment and the need to change the tourist offer if the industry is to be made more efficient in the region. Starting from the example of the CEE countries, Gannon (1994) analyzes how resources can be mobilized to help communities to make the transition from the agrarian economy to a sustainable and diversified economy, including through tourism, which is associated with economic, social, and environmental benefits.

The development of the rural tourism in the CEE countries is constrained by regional instability depending on the economic policy measures adopted by each country, the individual pattern of external relationships and the context of the global tourism industry (Hall, 1998). Hall (1999) states that the region, as early as the beginning of the 1990s, had a different image for westerns, as it was associated with quality but incoherent services, that is a cheap destination in relation to some aspects such as food, transport, tourism sites, shopping, but expensive in relation to other aspects such as poor-quality hotel services most of the time. The rural and nature tourism have been greatly promoted by the CEE countries (Hall, 1999). Since these statements of Hall (1999), progress has been made without bringing the CEE states to the top of tourist destinations.

Even though we tend to associate rural tourism and agritourism with less developed countries such as the CEE, Busby and Rendle (2000) show that agritourism is dominant in the U.K., France, Germany and Austria, a classic example of new tourism that is developing at the moment where tourism receipts outweigh the receipts 
in agriculture, and whose effects are generally euphoric. According to Hall (2000) Poland has been promoted as a "natural" destination, Croatia has promoted itself as a cultural and nature-based destination, Slovenia has focused on the green tourism and Romania on the rural tourism.

Hall (2004) notes the importance of the rural environment and identifies three important aspects of the tourism development: however attractive the rural areas and however clean the environment may be, these qualities are threatened by the impact of tourism and recreational activities; the training of people to improve the supply of tourist services is either not possible or ignored so it does not help to improve the quality of the life of locals and to adapt the products specific to rural tourism; the rural tourism products are relatively isolated and require promotion and marketing efforts as each country, sub-region and sector has its own characteristics, aspirations and priorities.

The tourism in the CEE countries, according to Russell and Copp (1999), is characterized by an increase in the number of visitors since the 1990s, but the region continues to face the issue of infrastructure, the poor quality of accommodation, the inappropriate staff training, the economic policy deficiencies but also with the poorly promoted destinations, and tourists focus primarily on visiting major cities because the CEE region is confronted with problems which limit the capacity of tourism development.

The new members states of CEE have assumed the responsibility of economic and social convergence towards the European core. A study conducted by Johnson (2008) on these states, including those that joined the EU in 2004, highlights that, after a period of enthusiasm, they polarized in pacesetters and laggards; the first group comprises the Baltic States, Slovenia and Slovakia, and the second group comprises Greece, Poland, the Czech Republic and Hungary. The analysis excludes Romania and Bulgaria.

Given that, we see polarized opinions of the authors who analyzed the CEE states but also the tendency to associate, for the most part, the expansion of tourism in these countries with the rural environment which provides conditions for meeting sustainability criteria, and in the following we study the link between European growth and tourism in terms of influencing factors.

\section{Method and methodology}

The impact of the tourism activity upon the European economic growth was achieved on the basis of the macro indicators - GDP per capita, ITR (International Tourism Receipts) per capita, ITE (International Tourism, Expenditures) per capita - provided by the World Bank, related to the period 1995-2017, whose value is expressed in dollars, at constant prices, reported in 2010. 
The GDP per capita best describes the economic growth process of each country. The ITR measures the incomes from the international tourism which are nothing but the expenses incurred by foreigners in the territory of the country of destination. These include, according to the World Bank, the payments to national carriers for international transport, any prepayment made for goods and services received in the country of destination, but not the receipts for domestic passenger transport, which is calculated as an export weight. In our case, the ITR values are calculated per capita.

The ITE measures the expenses that domestic tourists make during their travels abroad, not including the expenses for the transport of passengers. The difference between ITR and ITE values is the net income (or net exports) of tourism per capita. If ITR is calculated as a percentage of exports, ITE is calculated as a percentage of imports.

The ITR per capita values were calculated by reporting the ITR rate to the exports per inhabitant which, in turn, we calculated by reporting the value of the exports to the total population.

$$
\begin{aligned}
& \text { ITR }=\operatorname{Exp} x \operatorname{ITR}(\%) \\
& \operatorname{Exp}_{\text {per capita }}=\frac{\operatorname{Exp}}{P o p}(1) \quad \rightarrow \quad \text { ITR }_{\text {per capita }}=\frac{\operatorname{Exp}}{P o p} \times \operatorname{ITR}(\%)(2)
\end{aligned}
$$

We calculated the ITE per capita values similar to those of ITR, as follows:

$$
\begin{aligned}
& \text { ITE }=\operatorname{Imp} \times \operatorname{ITE}(\%) \\
& \operatorname{Imp}_{\text {per capita }}=\frac{\operatorname{Imp}}{P o p}(3)
\end{aligned}
$$$$
\rightarrow \quad \mathrm{ITE}_{\text {per capita }}=\frac{\operatorname{Imp}}{P o p} \times \operatorname{ITE}(\%)(4)
$$

The difference between the ITR and ITE values represents net exports from international tourism (ITNE - International Tourism Net Exports) and shows the value of net gains from the international tourism activity. A positive value of ITNE shows that foreign tourists spent more money on the territory of the host country compared to the amounts spent by the residents of the respective state in other destinations than the country of origin.

We divided the EU27 countries into four groups, the Mediterranean countries MC (Cyprus, Greece, Italy, Malta, Spain, Portugal, Croatia), the Nordic countries NC (Denmark, Estonia, Finland, Latvia, Lithuania, Sweden), the Western European countries - WEC (Austria, Belgium, France, Germany, Ireland, Luxembourg, the Netherlands) and the interest group of Central and Eastern European countries EEC (Bulgaria, Czech Republic, Hungary, Poland, Romania, Slovakia and Slovenia). The criteria according to which we formed the groups are geographical (the location in the same geographical proximity), economic (countries sharing economic similarities) and according to the characteristics of the tourism sector. 
Figure 1: Value of ITR, ITE and ITNE, 1995-2017

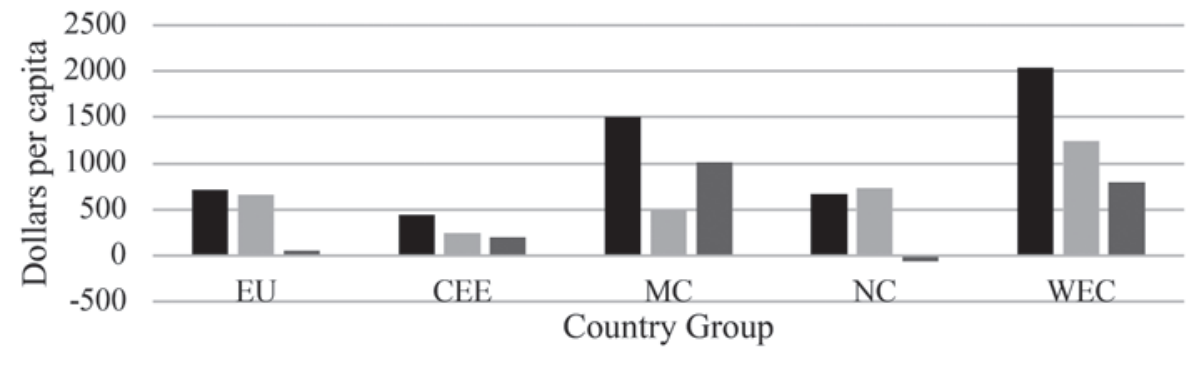

- ITR $=\mathrm{ITE}$ ITNE

Source: author's calculations based on World Bank data

The highest values of tourism receipts, per capita, between 1995-2017, were attracted by WEC followed by that of MC. WEC and MC obtained, per capita, tourism receipts above the European average, 2.9 times for WEC and 2.1 times for ME. The tourism income per inhabitant in the case of WEC exceeded 1.3 times that of MC. The NC and CEE groups were characterized by tourism receipts below the European average of $\$ 670$ per capita, respectively $\$ 442$ per capita, given that the EU average was $\$ 716$ per capita.

The expenditures made by Europeans for tourism show that the inhabitants of WEC and NC have spent more than the rest of the Europeans and above the European average. If a Western European spent, over the period 1995-2017, on average over $\$ 1240$ for tourism, and a resident of the northern states over $\$ 732$, a person living in a Mediterranean country has allotted over $\$ 488$, one person from the EEC allocated about \$247, while the European average was over \$ 662 .

Overall, EU27 was characterized by an average positive ITNE per capita value of approximately \$54. Only NCs registered negative values of ITNE, over \$ 61, which means that, as tourists, the inhabitants of the Nordic countries spent more in the destination states than the foreign visitors on their territory. In the case of the CEE group, a foreign tourist spent, between 1995 and 2017, on average of about \$ 195 more than a resident who visited other countries. The WEC countries obtained an ITNE value of approximately $\$ 802$, and those of $\mathrm{MC}$ over $\$ 1012$, which amounts to them in the hierarchy of states with high degree of tourist attractiveness.

We notice the differences between groups so that we intend to study the convergence capacity of the CEE group based upon ITRE values.

The impact of tourism on the economic growth will be done, in a first stage, through a deterministic sensitivity analysis, more precisely by calculating the elasticity coefficient of GDP per capita, as a dependent variable, according to the change in 
the number of foreign tourists flows and the net variation of the export of international tourism, as the input parameters, for the considered time interval.

The coefficient of elasticity $\left(\mathrm{E}_{\mathrm{Y} / \mathrm{X}}\right)$ expresses the relative variation of the dependent variable $(\Delta \mathrm{Y})$ in response to the variation with a percentage of the input parameter $(\Delta \mathrm{X})$, within a certain time horizon, according to the relation below, where $\mathrm{t}$ and $\mathrm{t}-1$ are the current period and the period considered as the reference base in the calculation of the relative change of the analyzed variables, $\mathrm{I}_{\mathrm{Y}}$ is the index of the dependent variable and $\mathrm{I}_{\mathrm{X}}$ is the index of the input variable.

$$
\mathrm{E}_{\mathrm{Y} / \mathrm{X}}=\frac{\Delta y}{\Delta x}=\frac{\frac{Y t-Y t-1}{Y y-1}}{\frac{X t-X t-1}{X t-1}}=\frac{I_{y}-100}{I_{x}-100}
$$

The high values of the elasticity coefficient show a high degree of sensitivity of the dependent variable to a slight modification of the input parameter.

To determine the relationship between growth and a series of independent variables, from tourism and not only, we use, into a second stage, two linear regression models.

The relationship between the economic growth of European states and tourism indicators is achieved with the help of a multiple regression analysis (model 1) in which the dependent variable is GDP per capita, and independent ones are tourism receipts per capita, tourism expenditures per capita and the number of tourists/flow of tourists/tourist arrivals. We opted for this choice because the effects of tourism can be measured with the help of tourism receipts and tourism expenditures in relation to GDP (Gavurova et al, 2020), these being measures of tourist demand (Rosselló-Nadal and He, 2019; Brida et al, 2020), to which we add other suggestive variables. Dogru et al (2020) consider that the growth in tourism is measured through tourism receipts and tourist arrivals (number of tourists) which together indicate the degree of tourism competitiveness. Consequently, the form of the regression equation (model 1) is:

$$
\begin{aligned}
\mathrm{GDP} & =\mathrm{E}(\mathrm{gdp} / \text { recep}, \text { expend }, \text { tournu })+\varepsilon \\
& =\beta_{0}+\beta_{2} \text { recep }+\beta_{3} \text { expend }+\beta_{4} \text { tournu }+\varepsilon,
\end{aligned}
$$

where GDP is the Gross Domestic Product per capita, recep is the receipts from tourism per capita, expend is the expenditures from tourism per capita, and tourno is the number of tourists, $\beta_{0}, \beta_{1}, \beta_{2}, \beta_{3}$ are the regression coefficients and $\varepsilon$ is the error term. For a higher acuity of the results we logarithmed the values of the indicators used.

The second linear regression model (model 2) includes, in addition to the independent variables of the first model, three more: capital stock, labor and exports. All the variables that contribute to the explanation of the great paradoxes and macroeconomic problems and all those that are found in the literature of economic growth are 
always correlated, directly or indirectly, with the capital stock (Escribá-Pérez et al, 2020). International tourism is a form of foreign trade, and all economic processes have an impact on the labor market, so we added these variables to the regression model. Thus, the theoretical regression equation becomes:

$$
\begin{gathered}
\text { GDP }=\mathrm{E}(\mathrm{gdp} / \text { recep, expend, tournu, stockcap, labor, exp })+\varepsilon \\
\mathrm{GDP}=\beta_{0}+\beta_{2} \text { recep }+\beta_{3} \text { expend }+\beta_{4} \text { tournu }+\beta 5 \text { stockcap }+\beta \text { labor }+\beta 7 \exp +\varepsilon,(7)
\end{gathered}
$$

Where stockcap is the capital stock, labor is the labor force and exp is total export, $\beta_{0}, \beta_{1}, \beta_{2}, \beta_{3}, \beta_{4}, \beta_{5}, \beta_{6}$ are the regression coefficients and $\varepsilon$ is the error term. In the regression analysis all the variables are related to the size of the population in order to eliminate the gaps that derive from the size of the researched economies and we used natural logarithms in the regression model.

Starting from the general research objective - the analyse of the tourism role on the European economy - we formulate the following research hypotheses:

$\mathrm{H1}$ : the incomes/receipts from international tourism support the European economic growth;

$\mathrm{H} 2$ : the flows of foreign tourists/number of tourists/tourist arrivals influence the European growth;

H3: the flows of foreign tourists/number of tourists/tourist arrivals is less important for the growth of European economies than the amount of expenditures which they are doing;

$\mathrm{H} 4:$ the tourism remains an activity with an important contribution to the growth of the European economy;

H5: the capital stock is the main determinant of the European economic growth, next tourism expenditures and exports, followed by the tourism variables.

\section{Results and discussions}

The main objective proposed for the analysis concerns, the role of the international tourism on the European economic growth, evaluated by the GDP values per capita and its influence by changing the flow of foreign tourists. We started from the premise that the incomes from international tourism (ITRE) play an important role in the growth of the tourism sector, implicitly in the European economic progress and in reducing the development gaps of the tourism sector under the conditions in which the economic growth depends also upon the tourism sector but not only.

To assess the impact of the international tourism on the economic growth of the European countries, we studied the relations between independent and dependent variables of two regression models based upon the equation mentioned (1-7) and thus, we validated the hypothesis of the research. 
The sensitivity analysis allows to verify the first two hypotheses proposed by the research, that is, whether the flows of foreign tourists and the net variation of the exports of international tourism influence the economic growth of the European countries in the analyzed time horizon and whether the flows of foreign tourists and the net variation of exports from international tourism influence the European economy. For the sensitivity analysis we calculated the average elasticity coefficients $\left(\mathrm{E}_{\mathrm{Y} / \mathrm{X}}\right)$ of the sub-periods 1996-2000, 2001-2005, 2006-2010 and 2011-2017. The economic growth is described by the evolution of the GDP per capita.

We calculated the GDP indices per capita $\left(I_{Y}\right)$, as a dependent variable, and of the international flows of tourists, respectively of the variation of the net exports from international tourism $\left(\mathrm{I}_{\mathrm{X}}\right)$, as independent variables, considering the year 1995 as a basis. For the both elasticity coefficients, the values the index of the dependent variable is the GDP per capita.

Table 1: Calculation of the elasticity coefficients of GDP per capita according to the variation of international tourist flows

\begin{tabular}{|c|c|c|c|c|c|}
\hline & \multirow{2}{*}{$\begin{array}{c}\text { The index of } \\
\text { the dependent } \\
\text { variable }\left(\mathrm{I}_{\mathrm{Y}}\right) \\
Y=P I B / \text { capita }\end{array}$} & \multicolumn{2}{|c|}{$\begin{array}{c}\text { Index of the } \\
\text { independent variable }\left(I_{x}\right)\end{array}$} & \multicolumn{2}{|c|}{$\begin{array}{l}\text { The coefficient of } \\
\text { elasticity }\left(E_{\mathrm{Y} / \mathbf{X}}\right)\end{array}$} \\
\hline & & $\begin{array}{c}X= \\
\text { international } \\
\text { flows of tourists }\end{array}$ & $\begin{array}{c}X=\text { net exports } \\
\text { from international } \\
\text { tourism }\end{array}$ & $\begin{array}{c}X= \\
\text { International } \\
\text { flows of tourists }\end{array}$ & $\begin{array}{c}X=\text { net exports } \\
\text { from international } \\
\text { tourism }\end{array}$ \\
\hline$E U$ & 22.80 & 43.16 & 36.20 & 0.07 & 0.44 \\
\hline \multicolumn{6}{|c|}{ Central and East European Countries (CEE) } \\
\hline Bulgaria & 55.03 & 48.22 & 4.83 & 1.16 & 0.49 \\
\hline Czech Republic & 34.66 & 93.12 & 4.42 & 4.62 & 0.63 \\
\hline Hungary & 39.60 & 26.52 & 15.93 & 1.15 & 0.73 \\
\hline Poland & 68.70 & -18.23 & 31.45 & 0.28 & 0.38 \\
\hline Romania & 51.08 & 28.24 & 323.37 & 2.27 & 0.28 \\
\hline Slovak Republic & 64.26 & 57.77 & 3.74 & 0.76 & -0.35 \\
\hline Slovenia & 42.91 & 141.63 & 20.55 & -0.34 & 0.56 \\
\hline \multicolumn{6}{|c|}{ Mediterranean Countries (MC) } \\
\hline Cyprus & 19.19 & 17.65 & 15.89 & 1.07 & 0.77 \\
\hline Croatia & 49.50 & 468.56 & 11.02 & 0.83 & 0.81 \\
\hline Greece & 24.35 & 57.64 & 18.42 & 0.62 & 0.88 \\
\hline Italy & 8.56 & 37.20 & 8.41 & 1.81 & 1.74 \\
\hline Malta & 38.23 & 21.69 & 19.53 & 0.56 & 0.96 \\
\hline Portugal & 19.62 & 7.83 & 26.25 & 0.88 & 0.68 \\
\hline Spain & 25.11 & 66.63 & 11.39 & 2.14 & 0.89 \\
\hline \multicolumn{6}{|c|}{ Nordic Countries (NC) } \\
\hline Denmark & 16.92 & 227.10 & -21.48 & -0.01 & 0.90 \\
\hline
\end{tabular}




\begin{tabular}{|c|c|c|c|c|c|}
\hline & \multirow{2}{*}{$\begin{array}{l}\text { The index of } \\
\text { the dependent } \\
\text { variable }\left(\mathrm{I}_{\mathrm{Y}}\right) \\
Y=P I B / \text { capita }\end{array}$} & \multicolumn{2}{|c|}{$\begin{array}{c}\text { Index of the } \\
\text { independent variable }\left(I_{x}\right)\end{array}$} & \multicolumn{2}{|c|}{$\begin{array}{l}\text { The coefficient of } \\
\text { elasticity }\left(\mathrm{E}_{\mathrm{Y} / \mathbf{X}}\right)\end{array}$} \\
\hline & & $\begin{array}{c}X= \\
\text { international } \\
\text { flows of tourists }\end{array}$ & $\begin{array}{c}X=\text { net exports } \\
\text { from international } \\
\text { tourism }\end{array}$ & $\begin{array}{c}X= \\
\text { International } \\
\text { flows of tourists }\end{array}$ & $\begin{array}{c}X=\text { net exports } \\
\text { from international } \\
\text { tourism }\end{array}$ \\
\hline Estonia & 93.11 & 280.29 & 16.05 & 0.19 & 0.21 \\
\hline Finland & 35.82 & 29.85 & -29.38 & 1.00 & 1.08 \\
\hline Latvia & 110.97 & 128.33 & -32.68 & -2.02 & 0.20 \\
\hline Lithuania & 106.50 & 155.38 & 49.16 & 0.78 & -0.04 \\
\hline Sweden & 30.45 & 100.98 & 33.51 & -1.23 & 0.94 \\
\hline \multicolumn{6}{|c|}{ Western European Countries (WEC) } \\
\hline Austria & 22.57 & 24.31 & 1.20 & 1.11 & 0.79 \\
\hline Belgium & 20.44 & 26.10 & 4.42 & 1.09 & 0.42 \\
\hline France & 16.66 & 28.82 & 37.20 & 1.18 & 0.50 \\
\hline Germany & 17.32 & 63.73 & 17.12 & 0.20 & 0.88 \\
\hline Ireland & 70.79 & 55.45 & 45.42 & 0.36 & 0.21 \\
\hline Luxembourg & 32.63 & 16.79 & 2.07 & 0.81 & 0.75 \\
\hline The Netherlands & 25.86 & 67.77 & -21.95 & 1.38 & 0.61 \\
\hline
\end{tabular}

Source: calculations made by the author

Taking as a basis of calculation for $\mathrm{E}_{\mathrm{Y} / \mathrm{X}}$ the year 1995, we notice, for the EU, the manifestation of a moderate average sensitivity of the GDP per capita to the slight variation of the international flows of tourists. On subperiods, the range 2011-2017 is characterized by a negative value of $\mathrm{E}_{\mathrm{Y} / \mathrm{X}}$. The $\mathrm{E}_{\mathrm{Y} / \mathrm{X}}$ values are negative for the CEE group, for Poland in the period after 2011 and for Slovenia for the period after 2001. The highest sensitivity of GDP per capita to the change in the number of foreign tourists is registered by the Czech Republic and Romania, followed by Bulgaria and Hungary. The MC and WEC groups are characterized by positive $\mathrm{E}_{\mathrm{Y} / \mathrm{X}}$ values, showing the dependence of the economic growth on the international tourism. In the MC group, Spain, Italy, Portugal, Cyprus and Croatia have the highest $\mathrm{E}_{\mathrm{Y} / \mathrm{X}}$ values.

The NC group is the least sensitive to the change arrivals of foreign tourists. Finland and Lithuania have a higher degree of GDP per capita change in the number of foreign tourists, while Latvia, Sweden and Denmark have the lowest. The WEC states represent an important group in terms of tourism, demonstrated by the $\mathrm{E}_{\mathrm{Y} / \mathrm{X}}$ values, representative for the Netherlands, France, Austria and Belgium. The only European countries for which $\mathrm{E}_{\mathrm{Y} / \mathrm{X}}$ experiences negative values are Slovenia, Denmark, Latvia and Sweden; one economy in the CEE group and three in the NC, illustrates a reduced sensitivity of GDP per inhabitant to the variation in the number of foreign tourists. 
The elasticity coefficient of the GDP per capita according to ITNE per capita experiences positive values for all the countries analyzed except Lithuania and Slovakia. The average value of $\mathrm{E}_{\mathrm{Y} / \mathrm{X}}$ in the case of Lithuania is -0.04, slightly suggestive, but on sub-periods we notice a low dependence of GDP per capita of ITNE. Hungary, the Czech Republic and Slovenia have a GDP per capita more sensitive to the variation in ITNE per capita compared to the other countries in the EEC group. Finland, Sweden and Denmark, in the NC group, have a relatively high GDP per capita elasticity to the ITNE variation.

The MC and WEC groups record values of the elasticity coefficient denoting a high sensitivity of the variable dependent of the independent variable. The Mediterranean states, in their entirety, experience a separation for the other states. The $\mathrm{E}_{\mathrm{Y} / \mathrm{X}}$ values, higher than those of the members of the WEC group, are specific to countries with a tradition in international tourism.

The GDP per capita is more sensitive to the variation in the number of foreign tourists than to that of the ITNE per capita in the case of Bulgaria, the Czech Republic, Hungary, Romania; from the CEE group; Cyprus, Italy, Portugal and Spain from the MC group; Lithuania from the NC group; Austria, Belgium, France and the Netherlands from the WEC group. For the other states, the values of $\mathrm{E}_{\mathrm{GDP} / \text { capita/no.of foreign tourists }}$ and $\mathrm{E}_{\mathrm{GDP} / \mathrm{capita} / \mathrm{ITNE} / \mathrm{capita}}$ are relatively equal or in favor of the coefficient of elasticity of GDP per capita according to ITNE per capita.

The multiple regression presents a positive relationship between the economic growth measured by the value of GDP per capita and the values of tourism receipts per capita, those of tourism expenditures per capita and the number of tourists. The results show that the tourism sector contributes significantly to European economic growth.

$$
\mathrm{GDP}=3.26906+0.03508 \text { recep }+0.71378 \text { expend }+0.12774 \text { tournu }
$$

The expenditures on tourism per capita has the biggest influence on European economic growth but also the number of tourists has an important impact. Receipts from tourism per capita have a lower impact on economic growth but also a positive one. The values of the regression parameters are included in a confidence interval between $2.5 \%$ and $97.5 \%$, as we show in the table 2 and table 3 .

Table 2: Confidence intervals for the 3 independent variables model (model 1)

\begin{tabular}{|l|c|c|}
\hline & $\mathbf{2 . 5} \%$ & $\mathbf{9 7 . 5} \%$ \\
\hline Intercept & 1.51563900 & 5.0224793 \\
\hline recep & 0.53297387 & 0.8945881 \\
\hline expend & -0.13768324 & 0.2078487 \\
\hline tournu & 0.05148837 & 0.2034494 \\
\hline
\end{tabular}

Source: calculations made by the author 
The results we have reached confirm the existing statements that tourism serves as a key economic activity and a major source of income for European countries with positive effects on employment, economic development and well-being (Hassani et al, 2017). In model 1 we show that, in the short term, tourism expenditures have an increased impact on economic growth, similar to the results obtained also by Usmani et al (2020). Konstantakis et al (2017) reach to a similar conclusion by emphasizing that less developed countries show an increased vulnerability to changing tourism expenditures whose source of origin is the dominant economies. Our analysis focuses mainly on Central and Eastern European economies which are part of economically emerging category, characterized by a high degree of vulnerability to Western European economies that are positioned on a dominant position according to Konstantakis et al (2017) study.

Regarding the tourism receipts, we showed that they have a positive impact but lower than tourism expenditures and tourism arrivals. Gnangnon (2019) shows, through an empirical analysis, that tourism receipts have a significant positive effect on state budget receipts and, therefore, indirectly on economic growth. This effect intensifies as the economy grows, indicating that the development of tourism tends to bring greater benefits to developed countries than to developing ones. In this context, our results are supported by those of Gnangnon's study (2019). In the situation of Central and Eastern European states, the impact of tourism receipts is expected to increase on an upward trend of growth in the conditions of a bicausal connection between variables.

Regarding tourism arrivals, we find a fairly high impact on economic growth. Artjones (2016) analyzes this link in relation to the satisfaction of the resident population. He notes that tourist arrivals reduce the satisfaction of the resident population, more pronounced in countries where the intensity of tourism is relatively high and in rural areas. The study also shows that tourist arrivals have an accentuated negative relationship with the evaluative component of subjective well-being, meaning the satisfaction of life, than the affective component, meaning the degree of happiness. Bădulescu et al (2018) reach to a conclusion similar to ours, confirming that between international tourism arrivals and economic growth and between international tourism receipts and economic growth, in the case of some Central and Eastern European countries, there is a long-term relation. Another study on Romania's case reveals that, on the short term, there is a unicausal relationship of international tourism receipts on growth and a bicausal relationship between international tourism arrivals and growth (Bădulescu et al, 2020), which again supports our results. 
Table 3: Confidence intervals for the 6 independent variables model (model 2)

\begin{tabular}{|l|c|c|}
\hline & $\mathbf{2 . 5} \%$ & $\mathbf{9 7 . 5} \%$ \\
\hline Intercept & $-6.934052 \mathrm{e}-02$ & 2.6381446 \\
\hline recep & $6.262083 \mathrm{e}-05$ & 2.6381446 \\
\hline expend & $-8.391396 \mathrm{e}-02$ & 0.3751944 \\
\hline tournu & $-1.546424 \mathrm{e}-01$ & 0.1128720 \\
\hline stockcap & $2.845278 \mathrm{e}-01$ & 0.7385607 \\
\hline labor & $-1.995207 \mathrm{e}-02$ & 0.2491277 \\
\hline exp & $-5.417962 \mathrm{e}-02$ & 0.2675202 \\
\hline
\end{tabular}

Source: calculations made by the author

Receipts from tourism per capita, expenditures per capita and the number of tourists explain $81.53 \%$ of the variation in the value of tourism production, which partially confirms the third hypothesis - H3 of the research.

Table 4: Bivariate correlation coefficients

\begin{tabular}{|c|c|c|c|c|}
\hline & $g d p$ & recep & expand & tournu \\
\hline gdp & 1.0000000 & 0.5685817 & 0.8677035 & 0.1284667 \\
\hline recep & 0.5685817 & 1.0000000 & 0.6484972 & -0.1842236 \\
\hline expand & 0.8677035 & 0.6484972 & 1.0000000 & -0.1751659 \\
\hline tоurnu & 0.1284667 & -0.1842236 & -0.1751659 & 1.0000000 \\
\hline
\end{tabular}

Source: calculations made by the author

The correlation matrix shows the direct link between the variables. Expenditures per capita are crucial for economic growth through tourism, the link being strong and significant. A medium to significant intensity link is manifested between tourism receipts per capita and the growth of the sector. A weaker correlation is manifested between the number of tourists and GDP per capita. These results reflect the fact that the number of tourists is less important for the growth of European economies through tourism than the amount of spending that they make during visits to Europe, which validates the third hypothesis of the research, H3. There is a difference in the impact of per capita expenditures compared to per capita receipts from tourism. The explanation is that not all expenses incurred by tourists are translated into tourism receipts. These are expenses that tourists make on the territory of a country and that are included in the calculation of the production of other sectors than the tourist one. The link between receipts per capita and expenditures per capita is, according to the values of bilateral correlation coefficients, strong and relatively significant. The same cannot be said about the links between tourism receipts per capita and the number of tourists on the one hand, and on the other hand, between tourism expenditures per capita and the number of tourists. These links are inverse and of low intensity, 
which indicates that economic growth in tourism depends more on the financial contribution of the sector than on the quantitative flows of visitors. As a percentage, we can say that $86.77 \%$ of the variation of the economic growth of the tourist sector is explained by the variation of tourists' expenditures, over $56 \%$ by the variation of tourism receipts and only $12.84 \%$ of that by the number of tourists, and these findings support hypotheses $\mathrm{H} 1, \mathrm{H} 2, \mathrm{H} 3$ and $\mathrm{H} 4$.

The high intensity of the link between growth in tourism and the three variables is also demonstrated by the values of the multiple correlation coefficient $(0.8147)$ and the adjusted determination ratio (0.8353). The parameters of the regression model are statistically significant (Sigt $=0.000773 / 0.678866 / 2.28 \mathrm{e}-08 / 0.002021)$, but in the case of receipts only in conditions of a confidence level below $95 \%$. The calculated value of $F$ test (40.56), superior to the theoretical one (3.522), significantly explains the dependence between variables. In conclusion, we say that growth in European tourism depends directly on expenditures per capita and on receipts per capita and to a lesser extent on the quantitative flow of tourists. This conclusion validates the first three hypotheses of the research, and and partially hypothesis four.

By model 1 we proved the hypotheses $\mathrm{H} 1, \mathrm{H} 2, \mathrm{H} 3$. The $\mathrm{H} 4$ hypothesis is hypothetical validated, however, model 1 is not comprehensive to prove that $\mathrm{H} 4$ (tourism remains an activity with an important contribution to European economic growth) is indeed correct. In order to confirm the hypotheses $\mathrm{H} 4$ and H5, we need to introduce in the analysis some additional variables, which will explain the European economic growth. Thus, we finalize the multiple regression analysis with a second regression model (model 2) by including in the model 1 three more independent variables: capital stocks, labor and exports. Thus, the theoretical regression equation (7) becomes:

$$
\begin{aligned}
\mathrm{GDP}= & 1.28+0.16 \text { recep }+0.14 \text { expend }-0.02 \text { tournu } \\
& +0.51 \text { stockcap }+0.11 \text { labor }+0.11 \text { exp }
\end{aligned}
$$

The introduction in the analysis of three more impact factors for economic growth we notice the change of the regression equation. The capital stock, the labor force and the total export determine a much more important increase of the GDP per capita than the tourism through the prism of the three factors from which we started in the analysis. However, if an increase in the number of tourists generates an insignificant increase in economic growth, receipts and expenditures remain factors with a direct and positive impact, in the case of receipts the increase is higher than in the situation where we neglected the analysis of capital stock, labor and export. All regression coefficients are found in the confidence intervals, as shown in the tables 2 and 3.

The relation between GDP and the six variables is presented in Figure 2. The regression graphs show the correlation between the dependent variable and the independent ones according to the values of the obtained coefficients. Although regression coefficients have positive values, which we see graphically through the upward trendline, in some situations we see slow tendency of non-correlation. 
Figure 2: The Relation between GDP and the Explanatory Variables

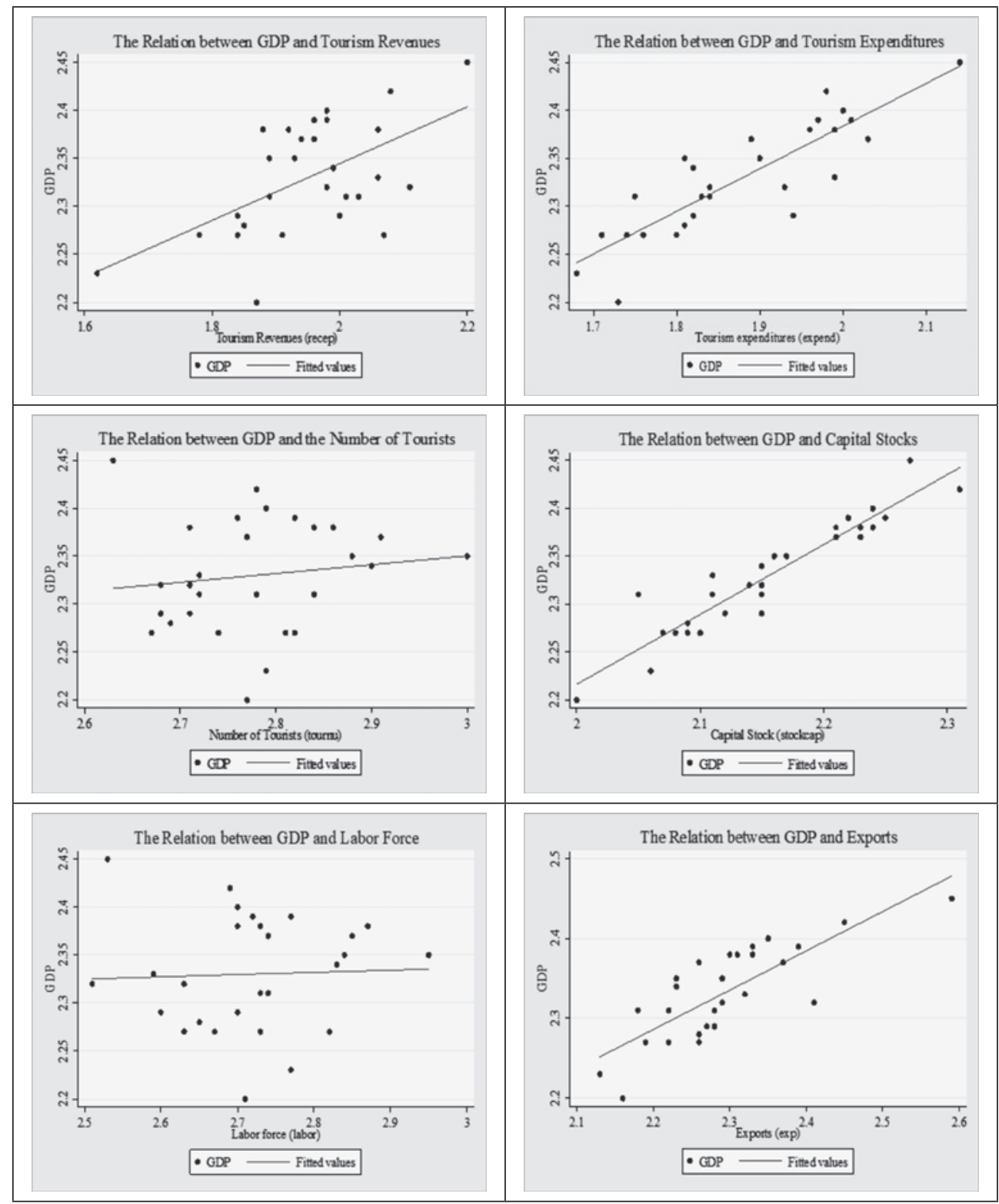

The regression graphs reflect the connection between the variables. We observe the positive correlation between growth and the explanatory variables, but the distribution of the point cloud shows differences between their impact on the growth. 
Table 5: Bivariate correlation coefficients

\begin{tabular}{|c|c|c|c|c|c|c|c|}
\hline & gdp & recep & expand & tournu & stockcap & labor & exp \\
\hline gdp & 1.000000 & 0.5685817 & 0.8677035 & 0.1284667 & 0.9384293 & 0.3903579 & 0.8051331 \\
\hline recep & 0.5685817 & 1.000000 & 0.6484972 & -0.1842236 & 0.4541137 & -0.4798075 & 0.6778266 \\
\hline expend & 0.8677035 & 0.6484972 & 1.000000 & -0.1751659 & 0.8824658 & -0.2742819 & 0.8752750 \\
\hline tournu & 0.1284667 & -0.1842236 & -0.1751659 & 1.000000 & 0.07559674 & 0.8824658 & -0.2880098 \\
\hline stockcap & 0.9384293 & 0.4541137 & 0.8824658 & 0.07559674 & 1.000000 & 0.01728928 & 0.7684444 \\
\hline labor & 0.3903579 & -0.4798075 & -0.2742819 & 0.8824658 & 0.01728928 & 1.000000 & -0.3815731 \\
\hline exp & 0.8051331 & 0.6778266 & 0.8752750 & -0.2880098 & 0.7684444 & -0.3815731 & 1.000000 \\
\hline
\end{tabular}

Source: calculations made by the author

From the table of bivalent correlation coefficients we observe that between the receipts from tourism and the European economic growth there is a direct connection of medium to significant intensity. The connection between the number of tourists and growth is positive of low intensity, and a positive connection of reduced intensity to average is manifested under the impact of the volume of labor force. European economic growth is positively and strongly correlated with capital stock, tourism expenditures and export. This affirmation supports the fourth and fifth research hypothesis, $\mathrm{H} 4$ and H5. Approximately $65 \%$ of the European growth variation is explained by the link between tourism receipts and tourism expenditures, $45.4 \%$ of that between tourism receipts and capital stock, and $67.8 \%$ of that between tourism and export receipts. European economic growth is significantly influenced by the link between tourism expenditures and capital stock, in proportion of $88.2 \%$, and between tourism expenditures and exports, in proportion of $85.5 \%$. The link between the number of tourists and the labor force has an impact of over $88 \%$ on European economic growth. From the bilateral correlation table we also notice the manifestation of some negative links of low intensity between growth and certain independent variables analyzed. For example, the link between tourism receipts and the number of tourists influences in proportion of $-18.4 \%$ the European economic growth, that between tourism expenditures and labor force in proportion of $-27.4 \%$, that between the number of tourists and exports in proportion of $-28.8 \%$, that between the labor force and exports in proportion of $-38.1 \%$, that the intensity of the negative influence to increase towards the average in the case of the connection between the incomes from tourism and the labor force in proportion of $-47.98 \%$. We mention that all these links are manifested when the others have an insignificant influence on the dependent variable, namely on the European growth. The table of correlation coefficients confirms the results previously obtained by the regression model with three independent variables.

In model 2 we inserted third variables with demonstrated significant influence on economic growth. Model 2, unlike model 1, shows a change in the influence of the number of tourists on growth when we expand the range of variables analyzed. Con- 
sidering the role of capital stocks, labor and exports, we notice that, unlike model 1 , the impact of tourism arrivals or number of tourists becomes slightly negative. The other variables prove their positive contribution, more or less significant. Thus, the results are reinforced by those of other studies. An analysis by Sharma \& Mitra (2020) points out that increasing the number of tourists by 1000 will have an effect on the labor market because it increases the number of jobs in tourism and related fields by 83.8 , and when the number of tourists decreases by 1000 the number of jobs is reduced by 29.8 . These results certify that the labor market is relatively socially and economically stable in terms of reducing the number of tourists. A study made by Harb \& Bassil (2020) shows that the relationship between tourism arrivals and growth is conditioned by the degree of education of the resident population. Destinations where locals have a higher degree of education benefit the most from the tourism development, which shows the importance of human capital in increasing the opportunity to attract tourists. Whether to maximize the results of the tourism industry depends on the resources allocated to human capital and investments made in order to improve the education of residents. Pérez-Rogriguez et al (2020) note that the relationship between tourism, tourist arrivals and growth is not stable over time and is highly dependent on economic events, conclusion that approaches to the result of the model 2.

The capital stock is related to tourism and growth alike. Brida et al (2020) argue that tourism contributes positively to economic growth, stimulates investment, competition in the labor market, research and development and it is a channel for technology diffusion.

Pérez-Rogriguez \& Santana-Gallego (2019) point out that tourism receipts have important implications for tourist destinations especially for local budget and for economic policies in the tourism sector, being considered significant financial assets which reveals, as our study shows, a dependency between them and economic growth. Sokhanvar (2019) mentions that tourism receipts and investments are critical factors in accelerating economic growth but, surprisingly, he finds that investments, in some cases, have a negative impact on growth without stimulating the tourism industry, which contradicts the result obtained by model 2 .

The model 2 shows that the variation of growth is explained to the extent of over $94 \%$ by the simultaneous variation of the six independent variables as opposed to the previous model in which the variation of growth is explained in proportion of $83.53 \%$ by that of variables that directly describe the tourism sector.

The high intensity of the link between the variables is confirmed by the values of the determination ratio lower than those of the determination coefficient in the case of both models (tables 6).

The regression parameters were tested in the classical mode, with the help of the $\mathrm{t}$ test whose theoretical value is 2.101 . The calculated values show that, except for the capital stock, the linearity link between growth and the analyzed determinants is confirmed. In the case of capital stock, the variability link is verified if we considered a lower level of confidence. 
Table 6: ANOVA for Model 1 and Model 2

\begin{tabular}{|c|c|c|c|}
\hline Coefficients & Estimate & $t$ value & $\operatorname{Pr}(>|t|)$ \\
\hline \multicolumn{4}{|c|}{ Model 1} \\
\hline (Intercept) & 3.26906 & 3.848 & 0.000773 \\
\hline expend & 0.71378 & 8.148 & $2.28 \mathrm{e}-08$ \\
\hline recep & 0.03508 & 0.419 & 0.678866 \\
\hline tournu & 0.12747 & 3.463 & 0.002021 \\
\hline Multiple R-squared & \multicolumn{3}{|c|}{0.8353} \\
\hline Adjusted $R$-squared & \multicolumn{3}{|c|}{0.8147} \\
\hline t test theoretical value & \multicolumn{3}{|c|}{2.080} \\
\hline F test & \multicolumn{3}{|c|}{40.56} \\
\hline F test theoretical value & \multicolumn{3}{|c|}{3.522} \\
\hline p-value & \multicolumn{3}{|c|}{$1.482 \mathrm{e}-09$} \\
\hline \multicolumn{4}{|c|}{ Model 2} \\
\hline (Intercept) & 1.28440 & 1.973 & 0.061792 \\
\hline expend & 0.16193 & 2.080 & 0.049919 \\
\hline recep & 0.14564 & 1.319 & 0.201238 \\
\hline tournu & -0.02089 & -0.325 & 0.748609 \\
\hline stockcap & 0.51154 & 4.686 & 0.000126 \\
\hline labor & 0.11459 & 1.771 & 0.091040 \\
\hline $\exp$ & 0.10667 & 1.379 & 0.182367 \\
\hline Multiple $R$-squared & \multicolumn{3}{|c|}{0.9428} \\
\hline Adjusted $R$-squared & \multicolumn{3}{|c|}{0.9265} \\
\hline t test theoretical value & \multicolumn{3}{|c|}{2.101} \\
\hline F test & \multicolumn{3}{|c|}{57.71} \\
\hline F test theoretical value & \multicolumn{3}{|c|}{2.901} \\
\hline p-value & \multicolumn{3}{|c|}{$5.777 \mathrm{e}-12$} \\
\hline
\end{tabular}

We tested the model with the help of the F test whose value, superior to the theoretical one (2.901) shows that the model explains, also in this case, the significant connection between the variables (tables 6 and 7).

Model 2 demonstrates the hypotheses $\mathrm{H} 1$ and $\mathrm{H} 3$ already confirmed by model 1 , but it refutes the hypothesis $\mathrm{H} 2$ (the flows of foreign tourists/number of tourists/tourist arrivals influence the European growth). When we introduce in the analysis more explanatory variables, the number of tourists becomes a less influential factor on the growth. Model 2 confirms the H4 hypothesis, but we notice that the role of tourism, although it remains important, is lower because economic growth reacts under the impulses of other factors such as capital stock, exports and labor force. In the context of the manifestation of several explanatory variables, we notice a strong connection between the capital stock and growth, but also between exports and growth, which confirms the H5 hypothesis. 
Empirical analysis shows that European tourism correlated with the effect of other factors has a direct and positive role on economic growth in the short time. The results we obtained are in agreement with those obtained by Martinis et al (2017) according to which tourism stimulates short-term economic growth through tourism arrivals and tourism expenditures, but our analysis extended the sphere of the explanatory variables of tourism activity and economic growth. The explanatory variables included in the two models are not the only ones that influence tourism and growth. In addition, it is necessary to keep in mind that can appear the effects of exogenous variables, some uncontrollable such as terrorist attacks, natural disasters, economic recessions, social and political instability (Silva et al. 2017) or, according to the experience of the year 2020, epidemics and pandemics.

\section{Conclusions}

The importance of tourism, its place and its economic and social effects determine us to analyze this activity as a growth and gap reduction factor for the Member States. The European tourism sector is significant as a share of GDP, therefore important for the economic growth. The EU is relatively heterogeneous in terms of tourism development, with CEE countries in full convergence of this activity. The CEE group is heterogeneous in terms of development. Howard \& Allen (2003) consider that the most developed economies in the region are Hungary and Poland, but they all make development efforts at different paces and with various results. Communication technologies, transport technologies, increasing incomes, the degree of urbanization and education have brought, among others, tourism to the rank of industry all over the world. The negative impact of tourism, especially on the environment and on the communities agglomeration, does not go unnoticed. Tourism is becoming more sustainable and imposes itself among the value-creating activities, being a process with direct, indirect and induced propagated effects.

Following the sensitivity analysis, we observe that the tourism sector plays an important role in the economic growth. We calculated the coefficient of elasticity by referring to 1995 as the base year. The calculation of the GDP per capita elasticity coefficient based upon the number of international tourists shows that all EU states except for Slovenia, Denmark, Latvia and Sweden have a certain degree of GDP per capita sensitivity to a small variation in the international tourist flow. By groups of countries, the least sensitive to the variation of international tourist flows is the NC group.

The coefficient of elasticity of the GDP per capita according to ITNE per inhabitant demonstrates the close connection between the two variables. The economic growth, described by the values of GDP per capita, depends upon the tourism sector, more precisely upon the surplus of the incomes attracted from international tourism over the expenses made by the residents of a country for tourist purposes, in other 
destinations than the homeland. We note the rigidity of GDP per capita in the variation of ITNE per capita in two cases. Lithuania and Slovakia registered negative values of the $\mathrm{E}_{\mathrm{PIB} / \mathrm{capita} / \mathrm{ITNE} / \mathrm{capita}}$ but the rest of the states are characterized by an increased sensitivity of the GDP per capita to a reduced variation of the ITNE. Sensitivity analysis validates the first two research hypotheses, $\mathrm{H} 1$ and $\mathrm{H} 2$, but the latter only to a certain extent. In this context, we opted for a linear regression with two models to study the link between growth and short-term tourism, including also other variables with an impact on growth.

The study of the relationship between independent variables specific to the tourism sector highlights the direct and positive relationship between growth, tourism expenditures and receipts. Even if the effect of tourist inflows is, in turn, direct and positive, the impact is lower than the other two variables analyzed. The ability to stimulate tourists to make expenses on the territory of the visited country and, implicitly to obtain increasing incomes from tourism, takes precedence over the ability to attract an increasing number of tourists. This aspect suggests to the European states that pursue the development of the tourism sector to orient their strategy towards attracting tourists from high-income countries and towards the development of those niches likely to generate high incomes. The first regression model confirmed the hypotheses $\mathrm{H} 1, \mathrm{H} 2, \mathrm{H} 3$ and partially $\mathrm{H} 4$ so we extended it by analyzing a second regression model.

We developed the initial regression model by adding three more independent variables that are not exclusive related to the tourism sector. It is about capital stock, labor and export. This second model shows the link between growth and the tourism sector. In fact, we found a direct positive link between economic growth and the six independent variables. Expenditures from tourism generate the increase of the capital stock, therefore of the investments and economic growth. The same effect is registered in terms of exports. We have seen that increasing the number of tourists supplements the labor force, reduces unemployment, and the effects on growth are also positive. Some pairs of independent variables have a negative effect on growth. The lowest negative influence is related to the number of tourists and tourism receipts. The rise in the number of tourists will change the volume of income and implicitly the growth process but the intensity remains debatable because there is no direct proportional link between the two independent variables. The connection with the strongest impact on growth is between tourism receipts and labor force. The reduction of receipts also determines the modification of the labor force volume. Increasing unemployment negatively affects the economic growth. Model 2 brought changes to the results obtained by model 1. If $\mathrm{H} 1, \mathrm{H} 3$ and $\mathrm{H} 4$ are again confirmed, $\mathrm{H} 2$ is refuted and, in addition, model 2 also confirms hypothesis H5.

The results we obtained are similar to those reached by Konstantakis et al (2017) regarding the role of tourism expenditures, to those reached by Guangnon (2019), Pérez-Rodriquez (2019), Bădulescu et al (2020) regarding the role of receipts from 
tourism, to those reached by Bădulescu et al (2019, 2020), Harb \& Bassil (2020) regarding tourism arrivals and investments, to those reached by Sharma \& Mitra (2020) regarding the role of the labor market, and to those reached by Usmani et al (2020) on the role of tourism expenditures on economic growth.

We analyzed and demonstrated that the process of economic growth of European countries is supported by the tourism sector. We also show the importance of tourism expenditures, tourism receipts but also of the stock capital and exports on European economic growth. In reality, tourist flows are not a stable growth factor. We can appreciate that, in the short term, capital stocks and tourism expenditure would be the factors with the most important role in European economic growth. The factors that influence, directly or indirectly, the tourist activity and implicitly the economic growth are numerous, impossible to be rendered in their complexity. This is one of the study limitations. Also, our analysis is a short-term one related to a relatively small number of variables. Using other time intervals, sample states or research methods is likely to lead to other results. The present analysis has its limitations; however, it highlights two important aspects.

First, from the viewpoint of the tourist activity, the convergence of the CEE countries is possible and the role of tourism remains important for the European economy. Secondly, tourism is not a panacea for economic growth and requires the effort to become sustainable. Although it is an important activity for the economy, especially in the case of tourism-intensive countries, our analysis shows that, even in the short term, other activities have a significant impact on the economy. The results we present not only complete the literature but also help on the line of economic policy and draw attention to the fact that development through tourism is not an end objective in itself but is as important as the development of investments in all fields, as exports development and labor market regulation. European countries, on the one hand, are encouraged to support tourism but on the other hand, according to the obtained results, they are warned about the need to change the strategies they apply and to adopt measures that will impose a more accentuated cadence to the tourism sector and, further, the accent will be on capital stock and exports like main determinants of economic progress.

A more extensive study, carried out on other samples and temporal horizons, with other methods and indicators, could more accurately capture the phenomena studied, confirm or deny the obtained results. 


\section{REFERENCES}

Abicht, L., \& Freikamp, H. (2005). Trend Qualification in German Tourism. In Strietska-Ilina, O., Tessaring, M. (eds.), Trends and Skill Needs in Tourism, Office for Official Publications of the European Communities, Luxemburg, Cedefop Panorama Series, no. 115. http://www. cedefop.europa.eu/files/5161_en.pdf

Agnew, D., \& Maureen, V.D. (2001). Potential Impacts of Climate Change on International Tourism, Tourism and Hospitality Research, 3(1), 37-60. doi.org/10.1177/146735840100300104.

Ana, M.I. (2017). Tourism Industry in the New Europe: Trends, Policies and Challenges, Proceedings of the 11th International Conference on Business Excellence (PICBE), De Gruyter, 494-505. DOI: 10.1515/picbe-2017-0053.

Andrei, J.V., Mieila, M., \& Panait, M. (2017). Transformations of the Romanian Agricultural Paradigm under Domestic Economic Policy Reforms: An Analysis during 1960-2011, Land Use Policy, 67, 288-297. https://doi.org/10.1016/j.landusepol.2017.06.008.

Artjones, I. (2016). Happy Hosts? International Tourist Arrivals and Residents'Subjective Well-Being in Europe, IZA Disscusion Paper, no. 10087, Institute for the study of Labor (IZA), Bonn. http://hdl.handle.net/10419/145221.

Augustyn, M. (1998). National Strategies for Rural Tourism Development and Sustainability: the Polish Experience. Journal of Sustainable Tourism, 6(3), 191-209.DOI: 10.1080/09669589808667311.

Badulescu, A., Badulescu, D., \& Simut, R. (2018). The Complex Relationship Between International Tourism Demand and Economic Growth: An Analysis on Central and Eastern European Economics. Amfiteatru Economic, 20(Special No. 12), 935-950. DOI:10.24818/EA/2018/S12/935.

Badulescu, A., Badulescu, D., Simut, R., \& Dzitac, S. (2020). Tourism-Economic Growth Nexus. The Case of Romania, Technological and Economic Development of Economy, 22(4): 867-884. https://doi.org/10.3846/tede.2020.12532.

Bohdanowiez, P. (2005). European Hoteliers'Environmental Attitudes: Greening the Business. Cornell Hotel and Restaurant Administration Quaterly, 46(2), 188-204. DOI: 10.1177/ 0010880404273891.

Botezat, E.A., \& Benea, C.B. (2012). Stimulating the Potential of Local Resources in Order to Achieve Competitiveness in Romanian Tourism. Procedia Economics and Finance, 3, 1256-1261. https://doi.org/10.1016/S2212-5671(12)00305-X.

Brida, J.G., Gómez, D.M., \& Segarra, V. (2020). On the Empirical Relationship Between Tourism and Economic Growth, Tourism Management, 81, 104131. https://doi.org/10.1016/j.tourman.2020.104131.

Busby, G., \& Rendle, S. (2000). The Transition from Tourism on Farms to Farm Tourism. Tourism Management, 21(6), 635-642. https://www.deepdyve.com/lp/elsevier/the-transition-fromtourism-on-farms-to-farm-tourism-LofAcRTFzk.

Copp. B.C., \& Lvy, L.R. (2001) Networking Trends of Small Tourism Businesses in Post-Socialist Slovakia. Journal of Small Business Management, 39(4), 345-353. https://doi.org/10.1111/04472778.00031 .

Dabour, N. (2003). Problems and Prospects of Sustainable Tourism Development in the OIC Countries: Ecotourism. Journal of Economic Cooperation, 24,1, 25-62. http://www.sesric.org/files/ article/127.pdf.

Dogru, T., Suess, C., \& Sirakaya-Turn, E. (2020). Why Do Some Countries Prosper More in Tourism Than Others? Global Competitiveness of Tourism Development. Journal of Hospitality \& Tourism Research, XX(X), 1-42. Doi: 10.1177/1096348020911706.

Donchcheva, D. (2019). Economic Dimensions of Sustainable Tourism in Bulgaria. Trakia Journal of Science, 17(Suppl.1), 400-411. Doi: 10.15547/tjs.2019.s.01.066. 
Eglite, A., \& Kaufmane, D. (2019). Economic and Environmental Objectives of Tourism in Latvia. International Multidisciplinary Scientific GeoConference: SGEM, Sofia, 19(5.3), 195-200. http://doi.org/10.5593/sgem2019/5.3

Escribá-Pérez, F.J., Murgui-Garcia, M.J., \& Ruiz-Tamarit, J.R. (2020). The Devil is in Details; Capital Stock Estimation and Aggregate Productivity Growth - An application to the Spanish Economy, Portuguese Economic Journal. http://doi.org/10.1007/s10258-020-00187-z.

Figuet, J.M., \& Nenovsky, N. (2006). Convergence and Shocks in the Road to EU: Empirical Investigations for Bulgaria and Romania, William Davidson Institute, Working Paper Number 810. http://citeseerx.ist.psu.edu/viewdoc/download?doi=10.1.1.424.4900\&rep=rep1\&type=pdf.

Filipiak, B.Z., Dylewski, M., \& Kalinowski, M. (2020). Economic Development Trend in the EU Tourism Industry. Towards the Digitalization Process and Sustainability. Quality\&Quantity, 1-26. http://doi.org/10.1007/s11135-020-01056-9.

Fossati, A., \& Panella, G. (eds.). (2000). Tourism and Sustainable Economic Development, Kluwer Academic Publishers.

Gannon, A. (1994). Rural Tourism as a Factor in Rural Community Economic Development for Economies in Transition. Journal of Sustainable Tourism, 2(1-2), 51-60. DOI: $10.1080 / 09669589409510683$.

Gavurova, B., Ivankova, V., Rigelsky, M., \& Přivarová, M. (2020). Relations Between Tourism Spending and Global Competitiveness: An Empirical Study in Developed OECD Countries. Journal of Tourism and Services, 21(11), 38-54. Doi: 10.29036/jots.v11i21.175.

Gnangnon, S.K. (2019). Impact of International Tourism Receipts on Public Revenue in Developed and Developing Countries. Tourism Review. DOI: 10.1108/TR-07-2018-0090.

Gőssling, S., Peeters, P., Ceron, J.P., Dubois, G., Patterson, T., \& Richardson, B.R. (2005). The Eco-Efficiency of Tourism, Ecological Economiecs, Elsevier, 54(4), 417-434. https://ideas.repec. org/a/eee/ecolec/v54y2005i4p417-434.html.

Graham, B., \& Shaw, J. (2008). Low-Cost Airlines in Europe: Reconciling Liberalization and Sustainability. Geoforum, 39, 1439-1451. doi.org/10.1016/j.geoforum.2007.12.006.

Greg, R. (2005). Cultural Tourism in Europe, ATLAS - Association for Tourism and Leisure Education.http://www.tram-research.com/cultural_tourism_in_europe.PDF.

Grillakis, G.M., Koutroulis, G.A., Seiradakis, D.K., \& Tsanis, K.I. (2016). Implications of 20C Global Warming in European Summer Tourism. Climate Services, 1, 30-38. http://agris.fao.org/ agris-search/search.do?recordID=US201900129758.

Hall, C.M., Timothy, J.D., \& Duval, D.T. (2004). Security and Tourism. Towards a New Understanding?. Journal of Travel \& Tourism Marketing, 15(2-3), 1-18. DOI: 10.1300/J073v15n02_01.

Hall, D. (1998). Tourism Development and Sustainability Issues in Central and South Eastern Europe. Tourism Management, 19(5), 423-431. doi.org/10.1016/S0261-5177(98)00039-9.

Hall, D. (1999). Destination Branding, Niche Marketing and National Image Projection in Central and Eastern Europe. Journal of Vacation Marketing, 5(5), 227-238. doi.org/10.1177/1356766799 00500303.

Hall, D. (2000). Sustainable Tourism Development and Transformation in Central and Eastern Europe, Journal of Sustainable Tourism, 8(6), 441-457. DOI: 10.1080/09669580008667379.

Hall, D. (2004). Rural Tourism Development in Southeastern Europe. Transition and Search for Sustainability. International Journal of Tourism Research, 6, 165-176. https://doi.org/10.1002/ jtr.482.

Hall, D. (2011). Tourism Developmentin Contemporary Central and Eastern Europe: Challenges for the Industry and Key Issues for Researchers. Human Geographies - Journal of Studies and Research in Human Geography, 5.2, 5-12. doi.org/10.1016/S0261-5177(98)00039-9.

Harb, G., \& Bassil, C. (2020). Harnessing Cross-Region Disparities to Assess the Impact of Tourism on Regional Growth in Europe, Current Issues in Tourism. Doi: 10.1080/13683500.2020.1829566. 
Hassani, H., Silva, S.E., Antonakakis, N., Filis, G., \& Gupta, R. (2017). Forecasting Accuracy Evaluation of Tourist Arrivals. Annals of Tourism Research, 63, 112-127. http://ualresearchonline. arts.ac.uk/id/eprint/10740.

Havliková, M., Stupková, L.C., \& Plišková, L. (2019). Evaluation of Sustainable Tourism Potential of the Principle Giant Mountains Resorts in the Czech Republic. Environmental \& Socio-Economic Studies, 7(4), 26-35. Doi: 10.2478/environ-2019-0021.

Henriksson, R. (2005). The Role of ICT in Tourism and Related Changes in Skills: Electronic Commerce and Revenue Management. In Strietska-Ilina, O., \& Tessaring, M. (eds.). Trends and Skill Needs in Tourism, Office for Official Publications of the European Communities, Luxemburg, Cedefop Panorama Series, no. 115. http://www.cedefop.europa.eu/files/5161_en.pdf.

Herbert, T.D. (1996). Artistic and Literary Places in France as Touristic Attractions. Tourism Manegement, 17(2), 77-85. doi.org/10.1016/0261-5177(95)00110-7.

Horwath HTL (Hotel, Tourism, and Leisure). (2018). Asia-Pacific: Regional Tourism Trends. Market Report. www.horwathhtl.com

Howard, H., \& Allen, D. (2003). Cultural Tourism in Central and Eastern Europe: the Views of „Induced Image Formation Agents". Tourism Management, 26, 173-183. https://www.sciencedirect.com/journal/tourism-management/vol/26/issue/2

https://data.worldbank.org/indicator

https://pdf.sciencedirectassets.com/282136/1-s2.0-S2212567116X00068

Invest Europe. (2018). 2017 Central and Eastern Europe. Private Equity Statistics. https://www.investeurope.eu/media/727455/Invest-Europe-CEE-Activity-Report-2017-05072018.pdf

Iorio, M., \& Corsale, A. (2010). Rural Tourism and Livelihood Strategies in Romania. Journal of Rural Studies, 26, 151-162. https://www.academia.edu/2270992/Rural_tourism_and_livelihood_ strategies_in_Romania

Johnson, J. (2008). The Remains of Conditionality: The Faltering Enlargement of the Euro Zone. Journal of European Public Policy, 15(6), 826-841. DOI: 10.1080/13501760802196564.

Jurigova, Z. (2016). Tourism Analysis with the Czech Republic as the Focal Point, Procedia Economics and Finance 39, 305-312, Proceedings of 3rd Global Conference on Business, Economics, Management and Tourism, 26-28 November 2015, Rome, Italy.

Kantar, S., \& Svržnjak, K. (2017). Development of Sustainable Rural Tourism. Deturope - The Central European Journal of Regional Development and Tourism, 9(1), 26-34. https://www.deturope. eu/index.php?navi $=101 \&$ vol $=25$

Konstantakis, K., Soklis, G., \& Michaelides, P. (2017). Tourism Expenditures and Crisis Transmission: A General Equilibrium GVAR Analysis with Network Theory. Annals of Tourism Research, 66, 74-96. DOI: 10.1016/j.annals.2017.06.006.

Korez-Vide, R. (2017). Storytelling in Sustainable Tourism Management: Challenges and Opportunities for Slovenia. Journal of Advanced Management Science, 5(5), 380-386. Doi: 10.18178/ joams.5.5.380-386.

Lakner, Z., Kiss, A., Merlet, I., Oláh, J., Máté, D., Grabara, J., \& Popp, J. (2018). Building Coalitions for a Diversified and Sustainable Tourism: Two Case Studies from Hungary. Sustainability, 10(4), 1090. https://doi.org/10.3390/su10041090.

Lars, H., Mark, J.M., \& Alvaro, M. (2009). Potential Impacts of Climate Change on Tourism, a Case Study for Spain. Current Opinion in Environmental Sustainability, 1, 170-178. DOI: 10.1016/j. cosust.2009.10.011.

Marian, I. (2017). Rural Tourism and Agro-Tourism in Romania. "Ovidius" University Annals, Economic Sciences Series, XVII(2). http://stec.univ-ovidius.ro/html/anale/ENG/2017-2/Section\%20III/14.pdf

Marinescu, C., Csosz I., Martin S.C., \& Ciolac R. (2009). European Experience in the Field of Health Tourism. Overview of the Countries of the Western Europe, Central and Eastern Eastern Europe. Management Agricol, 11(4), 279-288. https://lsma.ro/index.php/lsma/issue/archive. 
Martinis, L.F., Gan, Y., \& Ferreira-Lopes, A. (2017). An Empirical Analysis of the Influence of Macroeconomic Determinants on World Tourism Demand. Tourism Management, 61, 248-260. http://dx.doi.org/10.1016/j.tourman.2017.01.008.

Mckerscher, B., \& Lew, A. (2004). Tourist Flows and the Spatial Distribution of Tourists. In Lew, A., Hall, M., \& Williams, A. (eds.). A Companion to Tourism, Blackwell Publishing. http://apps. hevs.ch/blog/getfilesFTO.aspx?id=825.

Narkūnienè, R. (2019). Sustainability Aspect of Tourism Development in the East Aukštaitija Region, in Lithuania. Proceedings Of The International Scientific Conference Society. Integration. Education. VI, May 24th -25th, 420-429.

Nordin, S. (2003). Tourism Clustering and Innovation. Paths to Economic Growth and Development. ETOUR (European Tourism Research Institute). Utredningsserien Analys och. Statistik. http://www.diva-portal.org/smash/get/diva2:352389/FULLTEXT01.pdf

Nowacki, M., Kowalczyk-Anioł, J., Królikowska, K., Pstrocka-Rak, M., \& Awedyk, M. (2018). Strategic planning for sustainable tourism development in Poland. International Journal of Sustainable Development \& World Ecology. DOI: 10.1080/13504509.2018.1432513.

Okumus, I., \& Erdogan, S. (2021). Analyzing the Tourism Development and Ecological Footprint Nexus: Evidence from the Countries with Fastest-Growing Rate Tourism GDP. In Balsalobre-Lorente D. et al (eds.). Strategies Tourism Economic Growth and Clean Energy, Springer, Cham. 141-154. https://doi.org/10.1007/978-3-030-59675-0_8.

Pérez-Rogriguez, J., \& Santana-Gallego, M. (2019). Modelling Tourism Receipts and Associated Risks, Using Long-range Dependence Models. Tourism Economics, 1-28. Doi: 10.1177/ 1354816619828170 .

Pérez-Rogriguez, J., Rachinger, H., \& Santana-Gallego, M. (2019). Testing the Validity of the Tourism - Led Growth Hypothesis under Long-Range Dependence. Current Issues in Tourism, 1-27. Doi: 10.1080/13683500.1744537.

Radovanov, B., Dudic, B., Gregus, M., Marcikic Horvat, A., \& Karovic, V. (2020). Using a two-Stage DEA Model to Measure Tourism Potential of EU Countries and Western Balkan Countries: An Approach to Sustainable Development. Sustainability, 12, 4903. Doi: 10.3390/su12124903.

Rasoolimanesh, M., Ramakrishna, S., Hall, C.M., Esfandiar, K., \& Seyfi, S. (2020). A Systematic Scoping Review of Sustainable Tourism Indicators in relation to Sustainable Development Goals. Journal of Sustainable Tourism, 1-23. http://doi.org/10.1080/09669582.2020.1775621.

Raţiu, R.F., \& Oroian, M. (2012). Continous Professional Training - The Condition for the Romanian Tourism Survival, Procedia-Social and Behavioral Sciences, 46, 5626-5630. doi.org/10.1016/ j.sbspro.2012.06.485;

Richards, G. (ed.). (1996). Cultural Tourism in Europe, CABI, Wallingford, UK. http://www.tram-research.com/cultural_tourism_in_europe.PDF.

Robinson, M., \& Picard, D. (coord.). (2006). Culture, Tourism and Development, Division of Cultural Policies and Intercultural Dialog, UNESCO. https://unesdoc.unesco.org/ark:/48223/ pf0000147578.

Rosselló-Nadal, J., \& He, J. (2019). Tourist Arrivals versus Tourist Expenditures in Modelling Tourism Demand, Tourism Economics, 1-16. Doi: 10.1177/1354816619867810.

Russell, L.I., \& Copp, B.C. (1999). Tourism Patterns and Problems in East Central Europe. Tourism Geographies, 1(4), 425-442. https://doi.org/10.1080/14616689908721335.

Ruukel, A., Reimann, M., \& Tooman, H. (2020) Rural Tourism as a Tool for Sustainable Development: Lessons Learned in Estonia. In Slocum, S., \& Klitsounova, V. (eds). Tourism Development in Post-Soviet Nations. Palgrave Macmillan, Cham. https://doi.org/10.1007/978-3-030-30715-8_2.

Serdane, Z., Maccarrone-Eaglen, A., \& Sharifi, S. (2020). Conceptualising slow tourism: a perspective from Latvia. Tourism Recreation Research, 1-14. Doi:10.1080/02508281.2020.1726614. 
Sharma, J., \& Mitra, K.S. (2020). Asymmetric Relationship between Tourist Arrivals and Employment, Tourism Economics, 1-19. Doi: 10.1177/135481662091000.

Sharpley, R. (2020). Tourism, Sustainable Development and Theoretical Divide: 20 Years On. Journal of Sustainable Tourism, 28(11), 1932-1946. Doi: 10.1080/09669582.2020.1779732.

Silva, E.S., Ghodsi, Z., Ghodsi, M., Heravi, S., \& Hassani, H. (2017). Cross-Country Relations in European Tourists Arrivals. Annals of Tourism Research, 63, 151-168. http://dx.doi.org/10.1016/j. annals.2017.01.012.

Sokhanvar, A. (2019). Does Foreign Direct Investment Accelerate Tourism and Economic Growth within Europe?. Tourism Management Perspectives, 29, 86-96. https://doi.org/10.1016/j. tmp.2018.10.005.

Štefko, R., Vašaničová, P., Litavcová, E., \& Jenčová, S. (2018). Tourism Intensity in the NUTS III Regions of Slovakia. Journal of Tourism and Services, 9(16), 45-59. https://doi.org/10.29036/ jots.v9i16.43

Strietska-Ilina, O., \& Tessaring, M. (eds.). (2005). Trends and Skill Needs in Tourism, Cedefop Panorama Series, no. 115, Luxemburg: Office for Official Publications of the European Communities. http://www.cedefop.europa.eu/files/5161_en.pdf.

Tătar, C.F., Herman, G.V., \& Gozner, M. (2018). Tourist Guides Contribution to Sustainability in Romania. GeoJournal of Tourism and Geosites, 21(1), 282-287. Doi: 10.30892/gtg.21122-287.

Tsai, H.C. (2007). Agricultural Globalization and Rural Tourism Development in Taiwan, Asian Journal of Management and Humanity Science, 2(1-4), 1-13. http://asiair.asia.edu.tw/bitstream/310904400/2119/1/01.pdf

UNWTO. (2018a). Tourism Highlights, 2018 Edition. DOI: 10.18111/9789284419876.

UNWTO. (2018b). Tourism Investment 2018. Global Greenfield Investment Trends in Tourism,FDI Intelligence, A Publication from the Financial Times. https://www.fdiintelligence.com/Special-Reports/Tourism-Investment-2018-global-greenfield-investment-trends-in-tourism?ct=true?gclid=EAIaIQobChMI_vbps6-W4wIVihXTCh2OeAv9EAAYASAAEgLsv_D_BwE.

UNWTO. (2019). International Tourism Results 2018 and Outlook 2019, January. http://cf.cdn.unwto. org/sites/all/files/pdf/unwto_barometer_jan19_presentation_en.pdf.

Usmani, G., Akram, V., \& Praveen, B. (2020). Tourist Arrivals, International Tourists Expenditure, and Economic Growth in BRIC Countries. Journal of Public Affairs. http://doi.org/10.1002/ pa.2202.

Vodenska, M. (2020). Factors for (Un)Sustainable Tourism Development. Central European Journal of Geography and Sustainable Development, 2(1), 16-29. https://doi.org/10.47246/CEJGSD.2020.2.1.2

Weforum. (2019). The Travel and Tourism Competitiveness Report 2019. http://reports.weforum.org/ttcr.

Wojciech, B. (2012). Changes in level of Socio-Economic Development of EU Member Countries in the 2004-2013 Period - Taxonomic Analysis. Proceedings of the 3rd International Conference on European Integration, May 19-20, Ostrava, Czech Republic. https://www.ekf.vsb.cz/export/ sites/ekf/icei/.content/galerie-dokumentu/ICEI-2016_Sbornik_Komplet_Web_FINAL.pdf

Yang, C.L.E., \& Nair, V. (2014). Tourism at Risk: A Review of Risk and Perceived Risk in Tourism, Asia-Pacific Journal of Innovation in Hospitality and Tourism - APJIHT, 3(2), september, 239-259. www.academia.edu/30694918/Tourism_at_Risk_A_Review_of_Risk_and_Perceived_Risk_in_Tourism_Asia-Pacific_Journal_of_Innovation_in_Hospitality_and_Tourism_Tourism_at_Risk_A_Review_of_Risk_and_Perceived_Risk_in_Tourism.

Zarebski, P., Kwiatkowski, G., Malchrowicz-Mosko, E., \& Oklevik, O. (2019). Tourism Investment Gaps in Poland, Sustainability, 11, 6188. doi:10.3390/su11226188. 